\title{
Current state of knowledge regarding South America wetlands and their future under global climate change
}

\author{
Wolfgang J. Junk
}

Received: 6 July 2011/ Accepted: 15 February 2012/Published online: 28 March 2012

(C) Springer Basel AG 2012

\begin{abstract}
The exact size of the wetland area of South America is not known but may comprise as much as $20 \%$ of the sub-continent, with river floodplains and intermittent interfluvial wetlands as the most prominent types. A few wetland areas have been well studied, whereas little is known about others, including some that are very large. Despite the fact that most South American countries have signed the Ramsar convention, efforts to elaborate basic data have been insufficient, thereby hindering the formulation of a wetland-friendly policy allowing the sustainable management of these areas. Until now, the low population density in many wetland areas has provided a high level of protection; however, the pressure on wetland integrity is increasing, mainly as a result of land reclamation for agriculture and animal ranching, infrastructure building, pollution, mining activities, and the construction of hydroelectric power plants. The Intergovernmental Panel on Climate Change has predicted increasing temperatures, accelerated melting of the glaciers in Patagonia and the Andes, a rise in sea level of 20-60 cm, and an increase in extreme multiannual and short-term climate events (El Niño and La Niña, heavy rains and droughts, heat waves). Precipitation may decrease slightly near the Caribbean coast as
\end{abstract}

This article belongs to the Special Issue "Effects of Climate Change on Wetlands".

W. J. Junk $(\bowtie)$

National Institute for Science and Technology in Wetlands (INCT-INAU), Federal University of Mato Grosso (UFMT), Cuiabá, Brazil

e-mail: wjj@evolbio.mpg.de

W. J. Junk

State University of Amazonas (UEA),

Manaus, Brazil well as over large parts of Brazil, Chile, and Patagonia, but increase in Colombia, Ecuador, and Peru, around the equator, and in southeastern South America. Of even greater impact may be a change in rainfall distribution, with precipitation increasing during the rainy season and decreasing during the dry season. There is no doubt that the predicted changes in global climate will strongly affect South American wetlands, mainly those with a low hydrologic buffer capacity. However, for the coming decades, wetland destruction by wetland-unfriendly development planning will by far outweigh the negative impacts of global climate change. South American governments must bear in mind that there are many benefits that wetlands bring about for the landscape and biodiversity as well as for humans. While water availability will be the key problem for the continent's cities and agroindustries, intact wetlands can play a major role in storing water, buffering river and stream discharges, and recharging subterranean aquifers.

Keywords Wetlands - South America - Extent . Classification · Biodiversity · Management - Threats · Climate change

\section{Introduction}

South America comprises an area of 17.85 million $\mathrm{km}^{2}$ and is a sub-continent very rich in freshwater. Its large rivers, most importantly, the Amazon, Orinoco, Paranál Paraguay, Magdalena, and São Francisco, account for about one-fourth of all freshwater transported by rivers from all the continents to the sea. Total annual precipitation varies from a few tens of millimeters per year in the Atacama Desert to more than $5,000 \mathrm{~mm}$ per year at the foothills of the Andes near the equator and in boreal 
Patagonia. The precipitation shows an annual cycle, resulting in pronounced dry and rainy seasons over much of the continent as well as periodic flooding.

All large South American rivers and their tributaries, except the São Francisco and the Tocantins, pass over long stretches, through vast plains, and are accompanied by extended adjacent floodplains. All large rivers, except the São Francisco, have built up large deltas. Along the eastern coastline, mangroves and other coastal wetlands have developed. Furthermore, substantial areas of the interfluvial plains are periodically flooded by excess rainwater. These areas include wetlands along the middle and upper Negro River, the Pantanal of Mato Grosso, the Llanos de Moxos at the tributaries of the upper Madeira River, the floodable savannas at the Araguaia River including Bananal Island, the savannas of Roraima and Rupununi, the Llanos del Orinoco of Venezuela, and the wet Chaco of Argentina. In depressions all over the sub-continent, from lowland tropical rain forests and savannas to temperate and cold Patagonia and the high Andes, small to medium-sized wetlands store excess rainwater in the rainy season and release it to neighboring streams during the dry season.

The extent and diversity of wetlands account for their importance in most South American landscapes. Indeed, since the beginning of South America's colonization by humans, wetlands have played an essential role, providing food and shelter for hunter-gatherers. The edges of the lower Amazon River floodplain were colonized as early as $\sim 12,000$ years ago (Roosevelt 1999). The construction of elevated areas for flood protection has been described from all flooded savannas and also along the totora swamps (Schoenoplectus californicus ssp totora) around Lake Titicaca. Later on, when Europeans colonized South America, they used the large rivers for travel and transport, exploited fish and timber resources, and practiced agriculture and animal husbandry in the fertile floodplains. They also made use of many aspects of the traditional knowledge of the indigenous population and developed specific management methods well adapted to floodplain conditions. Indigenous terminology is often used for instance in the denomination of habitats of the Pantanal of Mato Grosso, which is one of the few examples of successful sustainable management of a tropical ecosystem by European immigrants through lowdensity cattle ranching.

The human population in South America has grown quickly, as has global demand for agricultural products and biofuels. The increasing political, economic, and technological power of South America has led to a dramatic rise in the exploitation of its natural resources and in the demand for land for agriculture and animal ranching, accompanied by the rapid development of infrastructure. Together, these changes have often occurred at the cost of wetlands, which are seldom considered in national development planning. This article summarizes the current state of knowledge about the ecology of South American wetlands, their extent and distribution, and their use, vulnerability, and protection. The analysis also considers global climate change scenarios and makes recommendations for a wetland-friendly policy in South America.

\section{Current knowledge about South American wetlands}

\section{Extension and typology}

South America covers a climatic gradient ranging from the tropics to the cold climate of Patagonia, an elevation gradient from low-altitude plains near sea level to mountainous regions and high plains of more than 4,000 m elevation, and vegetation units from cold to tropical deserts, cold to tropical savannas, and cold to tropical deciduous, semi-deciduous, and evergreen forests. Most parts of South America receive a surplus of precipitation but rainfall shows a pronounced dry and rainy season, except for the eastern slopes of the Andes. Therefore rivers and many wetlands show water level fluctuations and often pronounced aquatic and terrestrial phases. Rainfall is strongly influenced by El Niño Southern Oscillation (ENSO) events. During El Niño years, rainfall and river discharge in the Amazon basin are lower, during $\mathrm{La}$ Niña years higher than the average (Marengo and Nobre 2001).

The Amazon, Orinoco, and Paraná/Paraguay/La Plata Rivers occupy positions 1,3 , and 10 in the worldwide ranking of river discharge. Together, they transport about $8 \times 10^{12} \mathrm{~m}^{3}$ of water per year to the Atlantic Ocean (Milliman and Meade 1983; Meade 1996). Their drainage areas cover about $1 \times 10^{7} \mathrm{~km}^{2}$. The climatic and topographic diversity and the surplus of precipitation are reflected in the large variety of wetlands. Most rivers are accompanied by large fringing floodplains of different shapes and vegetation cover, according to flood regime and regional climate. These floodplains extend over thousands of kilometers in a west to east (Amazon and Orinoco Rivers), south to north (Magdalena River), or north to south (Paraná/Paraguay River) direction. South American mangroves cover an area of about 23,800 $\mathrm{km}^{2}$ (Lacerda 2001). The western coastline is arid but harbors large colonies of seabirds and seals, due to the cold and nutrientrich Humboldt current. In the endorheic basins of the high Andes, salt pans are present (Fig. 1).

However, information about the type and extension of wetlands in South America is still insufficient and contradictory. For instance, Junk (1993) estimated from vegetation and soil maps a wetland area of more than 2 million $\mathrm{km}^{2}$ for South America, whereas Eva et al. (2004) reported a wetland area of only about 


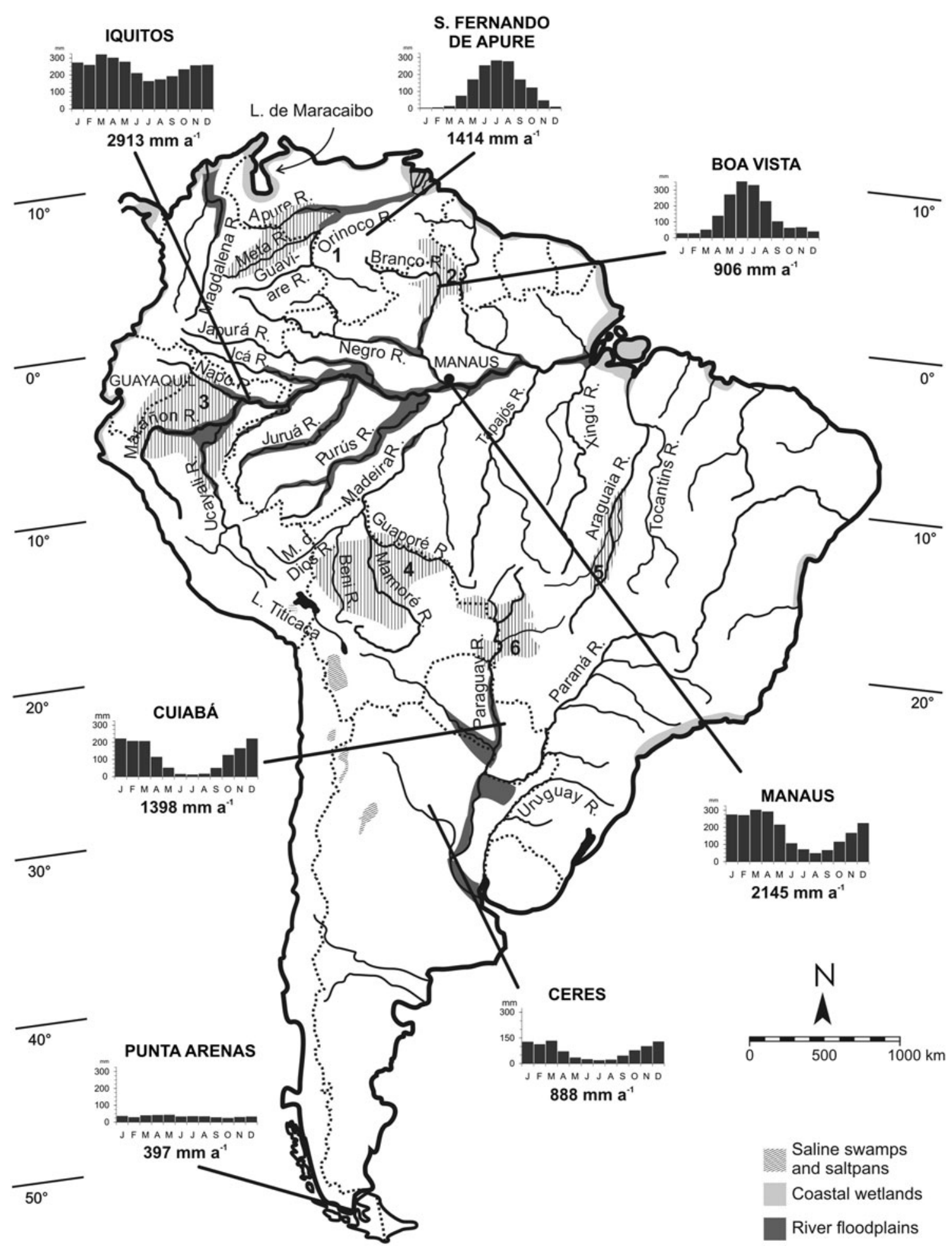

Fig. 1 Annual rainfall pattern and distribution of major SouthAmerican wetland types and wetlands. 1 Llanos del Orinoco, 2 periodically flooded savannas of Roraima and Rupununi, 3 Marañón-

1 million $\mathrm{km}^{2}$. Wetland delineation has made large progress because of the development of remote sensing techniques (Melack 2004). According to Melack and Hess
Ucayali palm swamps, 4 Llanos de Moxos, 5 periodically flooded savannas of Araguaia River, 6 Pantanal of Mato Grosso

(2010), total floodable area within the Amazon lowland basin (the region less than $500 \mathrm{~m}$ above sea level) at $100 \mathrm{~m}$ resolution is about $800,000 \mathrm{~km}^{2}$, or $14 \%$ of the entire area. 
But according to these authors, the actual floodable area is larger, because wetlands along low order rivers and scattered interfluvial wetlands were not recorded. For major South American wetlands, the following maximum areas are given: Llanos del Orinoco 105,454 $\mathrm{km}^{2}$ (Hamilton et al. 2004), periodically flooded savannas of Roraima and Rupununi $16,500 \mathrm{~km}^{2}$, Llanos de Moxos $92,100 \mathrm{~km}^{2}$, periodically flooded savannas of Araguaia River $58,600 \mathrm{~km}^{2}$ (Melack and Hess (2010), Pantanal of Mato Grosso 109,590 km² (Hamilton et al. 1996). Major gaps to be closed are: (1) Most wetlands vary considerably in size during the annual cycle of rainy and dry season. (2) There is a large interannual variability in the flooded area as shown by Sippel et al. (1998) for the Amazon River floodplain and by Hamilton et al. (2004) for the Llanos de Moxos, the Llanos del Orinoco and the Pantanal of Mato Grosso. Annual and interannual variability in size makes the definition of wetland boundaries often difficult. (3) Large areas are flooded or waterlogged only during relatively short periods of the year, and are therefore not recognized as wetlands, but the vegetation shows adaptations to waterlogged soils. (4) Inventories of small wetlands are insufficient, but their total area covers hundreds of thousand square kilometers. Rasera et al. (2008) estimate for the calculation of $\mathrm{CO}_{2}$ fluxes from small river channels ( 3 rd to 7 th river order) by remote sensing a surface area of about $300,000 \mathrm{~km}^{2}$. This calculation provides an idea about the order of magnitude of these systems but underestimates total wetland area which, per definition, includes periodically waterlogged areas adjacent to the river channel. Furthermore, wetlands of first and second order streams and periodically waterlogged depressions are not included. A synthesis of Junk et al. (2011c) considering small riparian wetlands along lower-order streams and rivers and periodically flooded savannas, campinas and campinaranas which have not yet been inventoried, resulted in an estimate for Amazonia of about 1 million $\mathrm{km}^{2}$, and a total wetland area of about 2 million $\mathrm{km}^{2}$, corresponding to about $30 \%$ of the Amazon basin.

For Argentinean wetlands, Neiff (2001) estimated an area of about 172,000 $\mathrm{km}^{2}$. Kandus et al. (2008), using soil parameters, concluded that about $600,000 \mathrm{~km}^{2}$ are wetlands, corresponding to $21.5 \%$ of the Argentinean territory. This percentage increases to $23 \%$ when permanent water bodies and saline areas are included. For entire South America, I estimate a total wetland area of more than 3 million $\mathrm{km}^{2}$, corresponding to about $20 \%$ of the land's surface. Some of the wetlands are well studied, such as the Pantanal, the Amazonian large river floodplains, and the Orinoco, Paraná and Paraguay River floodplains. Others are attracting in recent years increasing scientific attention, such as the Llanos de Moxos in Bolivia and the Araguaia River wetlands, while a third group has received little notice, such as the peat bogs of the Andean Altiplano and Patagonia, or is not considered as wetland, such as the Central Amazonian campinas and campinaranas, or are even considered as wastelands, such as the veredas in the Brazilian cerrado.

Sustainable management and protection of wetlands as well as comparative ecological studies require the classification of wetland types according to internationally accepted parameters. Several wetland scientists have already proposed regional classification systems. Neiff (2001) differentiated nine wetland types for Argentina using 12 parameters to characterize geomorphology, soils, fire stress, vegetation, animals, water origin, and several hydrological parameters. Brinson and Malvárez (2002) also differentiated nine major wetland types in Argentina but used the climate, hydrology, soils, and vegetation of geographic regions as criteria. The classifications for the Paraguay River system, including the Pantanal, of Wantzen et al. (2005) and Drago et al. (2008) are based on hydrogeomorphological characteristics. The habitat classification of the Pantanal proposed by Nunes da Cunha and Junk (2011) concentrates on the aquatic terrestrial transition zone and relies on hydrological properties, soil and water physicochemical characteristics, and botanical properties. This classification makes use as much as possible of local terms describing the Pantanal's geomorphology and vegetation units in order to increase acceptance by the local population of laws regulating the management of the region's habitats. Junk et al. (2011c) devised a classification system for the major Amazonian wetland types according to climate, hydrology, nutrient status of sediments and water, and vegetation cover. They distinguished 16 types covering tens of thousands of square kilometers but requiring further habitat classification for scientific and management purposes. This habitat classification is already well advanced for the large whitewater and blackwater river floodplains. Similar approaches are in preparation for the upper Paraná, Araguaia, and Guaporé River floodplains, carried out by the National Wetlands Research Institute (INAU) at Cuiabá, Brazil.

\section{Current knowledge and research efforts}

Most of the South American wetlands are flood-pulsing systems that oscillate between a terrestrial and an aquatic phase. The theoretical basis for the study of these systems was provided by the flood-pulse concept (FPC, Junk et al. 1989), which states that the flood pulse is the driving force in floodplain systems. It controls both the occurrence and the distribution of plants and animals, determines life-history traits, affects primary and secondary production, and influences decomposition and nutrient cycles in water and soils. Flood pulses vary in length, depth, frequency and shape. Their predictability facilitates the adaptation of 
organisms to the change between aquatic and terrestrial phases, increasing their ability to efficiently make use of periodically available resources. In temperate regions, the light/temperature (summer/winter) pulse, and in semiarid regions, the precipitation pulse (dry/rainy season), may overlap with the flood pulse, obscuring the impact of the latter. Large rivers and large interfluvial wetlands, such as the Pantanal, Bananal, Llanos de Moxos, and Llanos del Orinoco, show a predictable, monomodal flood pulse according to the annual rainfall periodicity in their catchments. The riparian vegetation of lower-order rivers is affected by an unpredictable polymodal flood pulse according to local and regional rainfall events. Mangroves and many coastal wetlands are affected by polymodal predictable pulses of the tide, interacting with local freshwater inflow, and wetlands in arid zones by less predictable pulses that may occur only every few years. For further discussions of the FPC, see Junk and Wantzen (2004) and Junk (2005).

Permanent wetlands with a rather stable water level occur in some headwater palm swamps in Amazonia and in swampy areas in the cerrado belt (veredas), chaco, the Andes, and Patagonia. They store large amounts of organic material, which in the case of Patagonia is being increasingly exploited for gardening purposes (Blanco and Balze 2004).

Despite the considerable amount of wetland research, both previous and ongoing, in South America, access to the results is often difficult and time consuming. Summaries exist, for instance, for the wetlands of Bolivia (Navarro and Maldonado 2002), Mamoré (Pouilly et al. 2004), Patagonia (Collantes and Faggi 1999; Blanco and Balze 2004), the Orinoco River (Vasquez 1989; Weibezahn et al. 1990; Lewis et al. 1990, 2000), Argentina (Malvárez and Bó 2004; Kandus et al. 2008; Baigún et al. 2008; Neiff 2001; Canevari et al. 1999), the Amazon region (Sioli 1984; Salo et al. 1986; Junk 1997a; Junk et al. 2000, 2010; Padoch et al. 1999; Kalliola et al. 1993; Goulding 1980; Goulding et al.1988, 1996; Smith 1999; Melack and Forsberg 2001; Melack et al. 2009), the Pantanal (Heckman 1998; Junk et al. 2011a), the Paraná River floodplain (Paoli and Schreider 2000; Thomaz et al. 2004; Iriondo et al. 2007), and the ephemeral wetlands in South America (summarized in Deil 2005).

In many universities, wetlands are the subject of research but there are only a few institutions with large teams concentrating on wetland research. Moreover, there is little cooperation among research groups, which weakens both the scientific performance and the political influence of wetland scientists. The following list provides some examples but is far from complete.

Argentina: Instituto Nacional de Limnologia (INALI) at Santa Fé, Centro de Ecologia Aplicada del Litoral (CECOAL/Conicet) at Corrientes, Grupo de Investigación sobre Ecologia de Humedales (GIEH) at the University of Buenos Aires.
Bolivia: Instituto para la Conservación de Ecosistemas Acuáticos-ICEA Santa Cruz, Red Nueva Cultura del Agua Bolivia Santa Cruz, Universidad Mayor de San Andres (UMSA), Universidad Tecnica del Beni (UTB).

Brazil: Instituto Nacional de Pesquisas da Amazonia (INPA) in Manaus, Instituto Nacional de Pesquisas e Technologia em areas Úmidas (INAU) in Cuiabá, EMBRAPA in Corumbá, NUPELIA in Maringa and the Universities of Manaus, Belem and Cuiabá.

Chile: Centro de Estudios Avanzados en Ecología y Biodiversidad (CASEB), Pontificia Universidad Católica de Chile, Instituto de Ecología y Biodiversidad (IEB), Universidad de Chile, SANTIAGO.

Colombia: Instituto de Ciencias Naturales, Universidad Nacional de Colombia, Instituto de Investigaciones Amazónicas, IMANI, Leticia, Departamento de Biología de la Universidade Nacional de Colombia, Departamento de Biologia, Grupo de Limnología de la Universidad de Antioquia, Medellín, Grupo GAIA, Universidad de Antioquia, Medellín.

Peru: The University of Iquitos, UNAS Humedales Perú Lima, Instituto de Recursos Naturales, INRENA, Lima.

Venezuela: Fundación La Salle (FLASA) and Instituto de Zoologia y Ecología Tropical IZET of the Universidad Central de Venezuela (UCV), Caracas, Centro de Ecología do Instituto de Investigaciones Científicas (IVIC.), Altos de Pipe and Centro de Investigaciones Ecológicas de Guayana of the Universidad Nacional Experimental de Guayana (UNEG), Ciudad Guayana.

In most cases, long-term and intensive research has concentrated on a few sensational large wetlands, e.g., the central and upper Amazon River floodplain in Brazil and Peru, the Pantanal of Mato Grosso and Mato Grosso do Sul in Brazil, the Paraná River floodplain in Brazil and Argentina, the Llanos del Orinoco in Venezuela, and some urban wetlands near large cities. Studies on coastal systems and large river floodplains are often initiated in response to problems related to fisheries (summarized in Junk 2007). By contrast, most other wetlands have been poorly studied and some not at all. This seems strange considering the large areas covered by these wetlands but may be due to the fact that many of them are situated in remote areas, far from universities and research institutes. In these regions, access is difficult and studies are expensive because of the lack of infrastructure and the long distances that must be repeatedly traveled. A major problem is the lack of political will to support wetland research. Wetlands are of low priority to the respective governments and indeed are often considered wastelands that could be drained to increase agricultural production or developed for other uses, such as housing, infrastructure, or fish culture. The multiple values provided by sustainably managed wetlands for the 
landscape and the human population pass mostly unnoticed by decision-makers and by the public.

Primary production, biomass, decomposition, and carbon storage

Primary production of South American wetlands varies considerably between wetland types and regions. The most productive are whitewater river floodplains in the tropical and sub-tropical lowlands, where floods deposit high amounts of fertile sediments and dissolved nutrients from the Andes. In the central Amazon várzea, herbaceous plants produce up to $100 \mathrm{t}$ dry matter ha ${ }^{-1}$ year $^{-1}$, phytoplankton and periphyton about $6 \mathrm{t}$, and the floodplain forest about $33 \mathrm{t}$. Biomass production is highest in the floodplain forests $\left(300-600 \mathrm{t} \mathrm{ha}^{-1}\right)$, decreases to $30-80 \mathrm{t} \mathrm{ha}^{-1}$ in herbaceous communities and, with $10-40 \mathrm{~kg} \mathrm{ha}^{-1}$, is lowest in algal communities (Junk 1997b). Mangroves along the coastline are highly productive, whereas most other wetlands show moderate to very low primary production because they develop on infertile soils and are fed by rainwater or receive water and sediments from rivers with a low nutrient status. Wetlands in savanna areas suffer additional drought stress for several months during the low-water stage, which further reduces primary production.

The accumulation of organic material in most South American wetlands is relatively low, as decomposition is accelerated during the low-water period, when organic matter becomes exposed to the air. In savanna areas, wild fires and frequent man-made fires are additional stress factors to fauna and flora, reducing the stocks of organic material. Exceptions are the relatively small patches of permanent swamps in Amazonia within the cerrado (veredas). At the Altiplano and in Patagonia, there are extended peat swamps. These swamps are of utmost importance for water balance in the respective regions, because they store rainwater and deliver it slowly to streams and subterranean aquifers. There is no information either about the total extent of these areas or the depth of the organic layer.

\section{Biodiversity}

According to Gopal et al. (2000, 2001), wetlands harbor a considerable part of global biodiversity. This is certainly evident in South America, where the total number of wetland species is very high, although exact numbers are missing for many groups of plants and animals. In general, species diversity decreases from the equator to the southern latitudes and from the lowlands to higher altitudes. More than 3,000 fish species are described from the Amazon River basin, more than 1,000 from the Orinoco River, 152 from the São Francisco River, 591 from the La Plata/Paraná/Paraguay River basin, 64 from the Andean Altiplano, and 17 from Patagonia (Junk 2007).

Compared to African floodable savannas, those in South America harbor a much smaller number of large herbivorous animals, in terms of species and abundance. The lower number of specimens cannot be ascribed to a low carrying capacity of the respective wetland systems for large ungulates because early travelers in the Pantanal reported seeing large herds of capybaras, swamp deer, peccaries, and tapirs. Furthermore large numbers of domestic animals (horses, cattle, and buffalo) live in most periodically flooded savannas. In 2004, about 3.4 million cattle lived in the Pantanal (SIDRA 2011). Competition for food by domestic animals is no argument for explaining the low number of game animals because they have a different food spectrum than cattle. Also, populations of game animals have not increased in the absence of domestic animals, such as under full protection in national parks. Junk et al. (2006) speculated that introduced diseases of domestic animals passed to game animals, dramatically reducing their populations, which have yet to develop the resistance needed for their numbers to increase again.

There are more than 1,000 highly flood-tolerant tree species in the Amazon River floodplain (Wittmann et al. 2010), whereas in the Pantanal this number decreases to about 355 (Junk et al. 2006), in Patagonia to about ten woody species, and at the Andean altiplano trees are absent. The diversity pattern of aquatic macrophytes contrasts considerably with that of fishes and trees. From a total of 387 herbaceous species of the central Amazon River floodplain, only 47 can be considered aquatic or palustrine because strong water-level fluctuations and light competition by the floodplain forest are limiting factors (Junk and Piedade 1993). The number increases considerably, to 248 species, in the shallowly flooded savanna areas of the Pantanal (Pott and Pott 2000). Alpha diversity of herbaceous species in Patagonian wetlands varies between 10 and 25 species, but wetland diversity and beta diversity are high (Collantes and Faggi 1999; Blanco and Balze 2004). Therefore, the total number of herbaceous hydrophytes in Patagonian wetlands may be as high as that in Amazonian large river floodplains.

The occurrence of endemic species varies between wetland systems and depends to a certain extent on their definition. The number of such species is relatively high in wetlands of the Amazon rain forest, the high Andes, mangroves, and probably in Patagonia. For instance, of the 1,000 tree species of the Central Amazon River floodplain (Wittmann et al. 2006), about $11 \%$ are considered endemic. But in most large interfluvial wetlands of the tropicalsubtropical cerrado and the temperate belt, the number of endemic species is low. These wetlands have a low 
hydrological buffer capacity and extreme drought events can eliminate entire populations of wetland organisms that lack drought-tolerant resting stages. While this hydrological instability also hindered speciation in these areas during geological time periods, the connection with large river systems allowed quick colonization by many wetland species from surrounding refuges as soon as conditions became more favorable, as shown for flora and fauna of the Pantanal of Mato Grosso (Junk et al. 2006).

Most South-American wetlands are intermittent and colonized by many terrestrial species of the surrounding uplands. This increases both the total number of species and the importance of the wetlands for the maintenance of regional biodiversity. From about 2,000 higher-plant species of the Pantanal, only about 600 are wetland species. An analysis of the 390 confirmed bird species reported from the Pantanal showed that only 104 are wetlanddependent. Also, many mammals and reptiles of the Pantanal are not wetland specific (Junk et al. 2006); a situation that may be characteristic of most wetlands in South American lowlands. On the other hand, the survival of some terrestrial species may be guaranteed because of healthy populations living in the wetlands. About $80 \%$ of the endangered hyacinth macaw population occurs in the Pantanal, where it is well protected and growing, while small upland populations are decreasing.

\section{Environmental values and benefits provided by the wetlands}

Wetlands provide many benefits to the landscape and to humans (Mitsch and Gosselink 2007; Gopal et al. 2008) (Table 1). These benefits cannot be separated because both humans and other, connected ecosystems make use of the wetlands. Mangroves, for instance, with their ample supply of fish and timber provide direct commercial opportunities to local people, but very important is also flood protection of ecosystems further inland, which support the people living there. Swampy areas in the savannas provide little direct commercial benefit to the local population, but maintenance of their biodiversity, carbon storage, watercleansing and groundwater-table recharging abilities, and their capacity to buffer the discharge of connected streams and rivers is important to the local human population and adjacent ecosystems.

Among the major wetlands, the highest commercial values are directly correlated with wetland fertility. River floodplains with high loads of fertile sediments and dissolved solids, e.g., the Amazon River and its whitewater tributaries, the Magdalena, Orinoco, and lower Paraguay Rivers, have a high fishery potential and their floodplains allow agriculture, timber exploitation, and cattle ranching.
Inland fisheries are of great importance for the protein supply of local populations throughout South America. Stocks in the Magdalena River of Colombia are heavily over-fished (Galvis and Mojica 2007), and those of the São Francisco and Paraná Rivers in Brazil are depleted (Sato and Godinho 2004; Agostinho et al. 2007). By contrast, the fishery potential of the Orinoco and Paraná/Paraguay Rivers is not fully exploited (Junk et al. 2007; Rodríguez et al. 2007; Quirós et al. 2007). Only half of the fishery potential of about 900,000 t year ${ }^{-1}$ of the Amazon River is used (Bayley and Petrere 1989).

Most of the rural population of the Brazilian states of Pará and Amazonas live in the fertile whitewater river floodplains. They practice subsistence fishery, agriculture, and cattle and water buffalo ranching, in addition to exploiting floodplain forests for timber. Near urban centers, they produce vegetables and fruits for the local market (Junk et al. 2000). In floodplains with lower fertility of water and soils, both total productivity and the size of human populations in the floodplains decrease. Clearwater river floodplains have a much lower potential for fishery, agriculture, cattle ranching, and timber production (Junk et al. 2011c).

Low-fertility blackwater floodplains have a very low production potential for fishery, agriculture and animal ranching. Timber production from tree species in the blackwater Negro River floodplain is only one-third of that in the whitewater Amazon River floodplain (Schöngart and Queiroz 2010). The value of these infertile floodplains lies in the maintenance of biodiversity, water-cleansing, buffering of water discharge, recharge of the groundwater table, and fire break. There is some commercial value, for instance, for ecotourism, subsistence fishery, and the collection of ornamental fishes, but these activities have to be carefully managed because of the high vulnerability of these systems.

Flooded savannas, such as the Pantanal, the Llanos de Moxos, the Llanos del Orinoco, and the wet Chaco, are suitable for low-density cattle ranching because of the natural vegetation cover of grasses and herbaceous plants. In the forested wetlands of the Amazon basin, the Orinoco floodplain, and the La Plata floodplain, cattle ranching is destructive because it requires the substitution of highly adapted floodplain forest by pastures, with negative impacts on timber production, biodiversity, and fisheries.

Riparian wetlands contribute to the well-being of the human population living in the surrounding areas: by the provision of water for domestic use, renewable wetland products, bathing, and other benefits. The economic value of urban wetlands has been little studied but recent investigations have suggested that they provide very valuable services, including clean water for domestic uses and wastewater treatment (Abe et al. 2006). 
Table 1 Most important benefits provided by major wetland types in South America

\begin{tabular}{ll}
\hline Type of wetland & Benefit \\
\hline Coastal wetlands & $\begin{array}{c}\text { Coastal protection, timber production, enhancement of fishery, maintenance of biodiversity, and recreation for } \\
\text { local people and tourists } \\
\text { Stream wetlands } \\
\text { local people, maintenance of biodiversity, retention of upland sediments and nutrients, and interconnection } \\
\text { of forest patches by riverine forest (thus promoting gene flow in forest plants and animals) }\end{array}$ \\
$\begin{array}{l}\text { Large riverine and interfluvial } \\
\text { floodplains }\end{array}$ & $\begin{array}{r}\text { Discharge buffering, water purification, groundwater recharging, provision of water, fish-breeding, provision } \\
\text { of renewable wetland products, maintenance of biodiversity, interconnection of forest patches by riverine } \\
\text { forests (thus promoting gene flow in forest plants and animals), home to local human populations, recreation } \\
\text { for local people, ecotourism }\end{array}$ \\
$\begin{array}{l}\text { Swamps and peat bogs } \\
\text { Salt pans }\end{array}$ & $\begin{array}{l}\text { Maintenance of biodiversity, periodic water storage, salt accumulation for industrial use (e.g., lithium in } \\
\text { Bolivian Altiplano salt pans) }\end{array}$ \\
\hline
\end{tabular}

\section{Current management plans, threats, and protection of wetlands}

\section{Management}

All South American governments have a general management plan for aquatic resources; however, the definition of what comprises aquatic resources is often insufficient. Colombia, for example, published a document describing its National Policy for Inland Wetlands (Ministerio del Medio Ambiente 2002). In Brazil, the management plan for water resources considers mostly the diversion of water from surface-water bodies and groundwater for different domestic, industrial, and agricultural purposes in addition to other uses, including navigation, hydroelectric power generation, and wastewater treatment. Wetlands, as such, are not defined in the plan and their management is not specifically considered. In the Brazilian constitution, there is only the general statement that the management plan should "promote the integration of the management of the water resources with management of the environment."

Most South American countries establish management plans for water resources on the basis of major river catchments, passing the responsibility for the elaboration of such plans to lower administrative levels, usually state governments. In most management plans, wetlands are not specified. Modern environmentally-friendly approaches, such as the Environmental Flow Assessment (King et al. 1999; Tharme 2003) successfully established in Australia and several South African countries, have not yet been adopted in South American countries.

\section{Threats}

South America has a population of 355 million people, corresponding to about 20 people $\mathrm{km}^{2}$. Most of the population is concentrated along the coastlines and in a few urban centers in the inner part of the continent. For example, the Brazilian state of Amazonas covers an area of about 1.57 million $\mathrm{km}^{2}$ and has a population of 3.3 million people, with about 2 million living in the capital of Manaus and another half million in a few smaller urban centers. The populations of other countries, such as Argentina, Bolivia, and Venezuela, are similarly concentrated in large cities. In large parts of many South American countries, the population density is less than two people per $\mathrm{km}^{2}$. However, even in these less densely settled areas, human activities can have major impacts and lead to large-scale modifications of the environment, including wetlands.

Pollution by liquid and solid wastes is a major problem in densely populated areas because wastewater treatment facilities lag far behind the demand of quickly growing cities. However, low population density in the countryside does not guarantee clean water and intact wetlands. For instance, agro-industries in the countryside contribute to pollution with pesticides and soil erosion. Despite the fact that erosion control has considerably improved during the last decade, soil erosion continues to be a serious threat to wetland habitats, diminishing habitat and species diversity in streams, rivers, and connected wetlands. The most dramatic example is the Taquari River, which drains into the Pantanal of Mato Grosso do Sul. Due to increased sediment load from agricultural areas into catchments of the high plains, the riverbed inside the Pantanal has risen to such a high level that an area of about $11,000 \mathrm{~km}^{2}$ is now flooded for much longer periods than was previously the case, with far-reaching negative consequences for flora, fauna, and ranchers (Galdino et al. 2006).

Agro-industrial complexes are responsible for the largescale transformation of natural vegetation to crop monocultures and pastures. Small and medium-sized wetlands are frequently located on private property and have been drained to expand agricultural production. In Mato Grosso's agricultural belt, many riverine wetlands have been 
destroyed down to the stream's edge, despite existing legislation that regulates the protection of these areas. All over South America, this type of wetland destruction goes mostly unnoticed by the public, because detailed inventories and maps of the different wetland types are lacking. Furthermore, current environmental legislation that deals with different wetland types is often contradictory and its implementation is not controlled, as shown for the Amazon River floodplain (Vieira 2000). The new version of the Brazilian forest code will dramatically reduce wetland protection in favor of agriculture (Sousa et al. 2011).

Large interfluvial wetlands, such as the Pantanal, the Bananal, the savannas of Roraima and Rupununi, the Llanos de Moxos of Bolivia, the Llanos del Orinoco of Venezuela, and the large river floodplains, will come under increased pressure to be made available for land reclamation aimed at agriculture, forestry, and intensive cattle ranching, as has occurred in the Paraná River delta in Argentina (Baigún et al. 2008).

Mining and related industries contribute to the pollution of water bodies and wetlands through dissolved and solid wastes, e.g., red mud from aluminum mining in Brazil (Bozelli et al. 2000) and contamination from petrol mining in Venezuela and Brazil, as demonstrated by the rupture of an oil pipeline at the Iguaçú River in southern Brazil in 2000. Toxic substances such as mercury from gold mining have affected wetlands in Brazil (Nogueira and Junk 2000), Peru, and Bolivia. Deforestation for charcoal production has accelerated to meet the demands of steel production, affecting wetland forests such as those of the Pantanal (Machado et al. 2011).

Aquaculture in South America is increasing such that it is becoming an important economic factor in several of the sub-continent's countries. However, negative impacts reflect, for example, the large-scale transformation of mangroves into aquaculture areas. Marine salmonid production in Chile grew dramatically, from $53 \mathrm{t}$ in 1981 to 350,000 t exported in 2004 (Pascual et al. 2007). Growth of this industry has been accompanied by high levels of environmental pollution. In Brazil, Colombia, and Venezuela, freshwater aquaculture is still in its early stages but the amount of freshwater in those countries favors its development. Around Lake Titicaca, fish culture is of great economic importance (Vila et al. 2007) but is associated with major risks from the escape of exotic species, associated parasites and diseases, and the creation and escape of hybrids and genetically modified specimens that place the natural genetic variability of stocks at risk. In the 1940s and 1950s, the epizootic protozoan parasite Ichthyophthirius multifiliis was probably introduced along with exotic fishes to Lake Titicaca, causing the death of 18 million Orestias in December 1981 (Wurtsbaugh and Tapia 1988). In the 1990s, the predatory peacock bass (Cichla ocellaris) was introduced to the Pantanal and it is now spreading in several areas, endangering the natural fish fauna.

Navigation is increasingly affecting major rivers and associated wetlands. In South America, the best-known example is the plan to rectify and channelize the Paraguay River along the stretch that passes through the Pantanal (hidrovia) (Huszar et al. 1999). This would dramatically alter the hydrology of the wetland, with consequent largescale modifications of the natural vegetation cover and animal populations. Increasing sediment load of the tributaries draining the agricultural belt of the upper Paraguay basin is clogging the river channels inside the Pantanal. Already today, ship traffic in the upper reach of the Paraguay River is hampered at low water by sand accumulation in the river channels. This situation will aggravate when the sediments from the tributaries reach the main channel.

A serious threat to large river floodplains is the accelerated construction of dams for hydroelectric power generation. In the year 2000, hydroelectric power accounted for most of the electrical energy of South American countries: Brazil 93\%, Paraguay 100\%, Peru 74\%, Venezuela $73 \%$, Ecuador $68 \%$, Colombia $68 \%$, and Chile $57 \%$ (World Commission of Dams 2000). In the future, increased reservoir construction is expected along most large and medium-sized South American rivers to provide electrical energy to urban centers and industrial pools.

In these times of increasing prices for fossil fuels and threats due to global climate change, the right and need of all countries to use the hydroelectric potential of the different river systems to foster their economic development is justified. However, it is essential to establish long-term strategies for the prudent use of this potential. Some rivers, such as the upper Paraná River in Brazil, have already been transformed into a series of hydroelectric reservoirs. This interrupts longitudinal connectivity, modifies discharge, sediment load and hydrochemical conditions, and destroys or modifies connected wetlands. The negative impacts on habitat and species diversity as well as fisheries have been well studied by the Research Institute (NUPELIA) in Maringá, Brazil. Its findings should be considered in any discussion of the construction of additional reservoirs.

A feasibility study for the Brazilian Amazon River basin cited 90 localities suitable for reservoirs, involving all major tributaries and with a potential of about $100,000 \mathrm{MW}$. These reservoirs would cover an area of about 100,000 km² (Junk and Nunes de Mello 1987). However, not all technically feasible reservoirs are economically justifiable when the total ecological and social costs and negative site-effects are considered, including the destruction and modification of river floodplains. A negative example is the Balbina Reservoir at Uatumã River, Amazonia, which was constructed to provide energy for the city of Manaus and its industrial park. The reservoir covers 
an area of about $2,360 \mathrm{~km}^{2}$ and inundated formerly undisturbed rain forest, but it produces $<900 \mathrm{MW}$, which is one of the lowest energy outputs per unit reservoir area worldwide and not enough for the city's requirements. Moreover, it will be a long-term source of methane release because of the large amounts of inundated organic material and the large aquatic-terrestrial transition zone (Fearnside 1989, 1995; Kemenes et al. 2007). Long-term strategies may cluster reservoirs in specifically suitable river basins, leaving other basins intact. Another option is to release water from existing reservoirs according to environmental needs, with the aim of diminishing negative environmental impacts instead of maximizing energy production. These approaches require multidisciplinary cooperation between engineers, socio-economists, and environmentalists, but in South America they are still in their infancy.

Reservoirs for hydroelectric power generation may also, either directly or indirectly, affect neighboring countries, i.e., those sharing a watershed. For instance, the planned hydroelectric power plants of San Antonio and Jirau, on the Madeira River will affect fish migration and fishery in Bolivia. Another example is the 5-m increase in the water level of the bi-national Argentinean/Paraguayan reservoir of Yacyretá, which affects 50,000 people in Paraguay through the partial inundation of the Paraguayan city of Encarnación.

Today, flood control is restricted to rivers in densely populated areas. In the highly modified upper Paraná River system, dike and reservoir construction has interrupted longitudinal and lateral connectivity between most river channels and their floodplains. In the majority of river systems, lateral connectivity between river channels and floodplains is still intact. Nevertheless, there is an increasing risk also for large wetlands in regions with low population density. Agro-industries may move into floodplains with low flood amplitude and start poldering for flood control, thereby modifying the hydrology inside and outside the polders. Consequently, there is a need to regulate the industrial use of wetland soil by implementing wetland-friendly alternatives. The most important threats are summarized in Table 2.

Compared to other regions in the world, wetland loss in South America is still relatively small, but there are no data available about the total area. Wetland loss affects mostly riparian wetlands of low order rivers, swampy areas in croplands, and, increasingly, large interfluvial wetlands which are transformed to cropland. Increasing wetland loss is also noticed for floodplain areas of large rivers inundated by hydroelectric reservoirs. The lack of environmental education accounts for the low level of public awareness regarding environmental destruction in general and wetland destruction specifically. The political and economic demands to increase food and biofuel production will, over the next few decades, dramatically increase the expansion of pasture and crop lands all over South America. A sound wetland policy is urgently required, recognizing that the maintenance of wetlands is always much cheaper and more effective than rehabilitation after degradation, and the economic benefits of most of the destructive practices are small or non-existent and will soon result in severe economic losses. The last aspect is of particular importance for South America, which has many large wetland areas still in rather pristine condition.

\section{Protection}

Most South American countries have signed the Ramsar Convention, which by Article 2.4 obliges each signatory to designate at least one wetland site for inclusion in the List of Wetlands of International Importance. The number and total area of Ramsar sites in South American countries are cited in Table 3. These data, however, give an incorrect view of the total protected wetland area. Recommendation 4.6 of the Ramsar convention urges Contracting Parties to "the establishment of wetland inventories, based on the best scientific information available at both national and international level". Here, all South American countries have serious deficits.

Since there are no detailed data available concerning either the total wetland area in South America or the area of protected wetlands, some general estimates may provide an idea of their order of magnitude. For instance, about 1.15 million $\mathrm{km}^{2}$ of the Brazilian territory are protected by different types of national parks and reserves. Another 1 million $\mathrm{km}^{2}$, corresponding to $12.5 \%$ of the national territory, have been declared as indigenous lands, used and controlled by small indigenous populations in a traditional low-impact manner. This corresponds to about $27 \%$ of Brazilian territory, most of it situated in the Amazon basin. These numbers will increase because there are several areas under consideration to receive the status of national parks, reserves, or indigenous territories. An additional $17 \%$ of Brazilian territory is protected as "Permanently Preserved Areas" (APPs), which include ecologically sensitive areas, such as river margins and hill slopes. The protection of APPs is precarious because most of them are contained within private properties and the owners often do not respect the relevant legislation. Actually, the protection status of APPs is under discussion and may become strongly reduced because of the pressure of the agroindustry (Sousa et al. 2011; Tollefson 2011). This would seriously affect the wetlands. The same is true for the $20 \%$ of agricultural area that should be protected as "Legal Reserve," but a considerable part has already been destroyed, mostly in southern Brazil. Given that most of the protected areas are situated in Amazonia, where the 
Table 2 Major threats to South American wetlands

\begin{tabular}{|c|c|}
\hline Reasons & Consequences \\
\hline $\begin{array}{l}\text { High densities of human } \\
\text { population }\end{array}$ & Pollution, land reclamation, water abstraction, diking, increased erosion \\
\hline Agro-industrial complexes & $\begin{array}{l}\text { Land reclamation, pollution by fertilizers and agro-toxics, water diversion, diking and poldering, increased } \\
\text { erosion }\end{array}$ \\
\hline Mining & Pollution by solid and liquid wastes, mercury intoxication \\
\hline Aquaculture & $\begin{array}{l}\text { Water pollution, wetland destruction, escape of exotic species, genetic pollution of fish stocks by population } \\
\text { mixing and hybridization }\end{array}$ \\
\hline Navigation & $\begin{array}{l}\text { Channelization, straightening of water courses, diking, water pollution, dredging spoils, disturbance of fish and } \\
\text { wildlife }\end{array}$ \\
\hline Generation of hydropower & $\begin{array}{l}\text { Change in water discharge, interruption of longitudinal connectivity, change in the load of suspended and } \\
\text { dissolved solids }\end{array}$ \\
\hline Flood control & Diking, interruption of lateral connectivity \\
\hline
\end{tabular}

Table 3 Number and total area of Ramsar sites designated by South American countries (as of December 2011)

\begin{tabular}{lcl}
\hline Country & No. of sites & Area (ha) \\
\hline Argentina & 20 & $5,339,826$ \\
Bolivia & 8 & $7,894,472$ \\
Brazil & 11 & $6,568,359$ \\
Chile & 12 & 358,989 \\
Colombia & 5 & 458,525 \\
Ecuador & 14 & 202,597 \\
French Guiana & 2 & 196,000 \\
Paraguay & 6 & 785,970 \\
Peru & 13 & $6,784,042$ \\
Suriname & 1 & 12,000 \\
Uruguay & 2 & 424,904 \\
Venezuela & 5 & 263,636 \\
Total & 99 & $29,289,320$ \\
\hline
\end{tabular}

percentage of wetlands with respect to the entire landscape may reach about $30 \%$, about 1 million $\mathrm{km}^{2}$ of Brazilian wetlands should be under some state of protection. For South America as a whole, this number may rise to 1.5 million $\mathrm{km}^{2}$. If we assume that about $20 \%$ of South America is wetlands (about 3.5 million $\mathrm{km}^{2}$ ), then about $40 \%$ of the wetland area is under some type of protection. This number seems to be high but the calculation is no doubt overly optimistic because the level of protection cannot be accurately quantified.

A major challenge for scientists is the need to determine and quantify the benefits that the different wetland types provide to society and the environment over the short, medium, and long term. This will strengthen arguments in favor of wise wetland use and protection. The high economic value of wetlands is demonstrated by the large amounts of money expended for wetland restoration in North America and Western Europe. The cost of important projects, such as rehabilitation of the Everglades, parts of the Mississippi River, and the Rhine River floodplains is in the billions of US\$. That these efforts are nonetheless being made shows that: (1) the economic benefits of wetland destruction are often outweighed by the negative side effects; (2) the economic framework changes quickly and modifies cost-benefit analyses of development projects, often in favor of intact wetlands; and (3) only parts of former wetland areas can be recovered to near-natural conditions, and at very high cost. The negative economic and social consequences of large scale destruction of natural vegetation on steep slopes and the transformation of wetlands for agriculture and civil construction can be observed in the Brazilian States of Rio de Janeiro and Minas Gerais, which are every year affected by disastrous land-slides and inundations during the rainy season.

\section{Wetlands and traditional human populations}

Ever since humans arrived on the South American subcontinent, they have favored wetlands, and all large wetlands show remnants of early human occupation. Hunter-gatherers colonized the lower Amazon floodplain 12,000 years ago and made use of its abundant fish, shellfish, and game animals (Meggers 1984, 1987; Denevan 1976; Roosevelt 1992, 1999). Earliest records of a sedentary life in the area date from about 8,000 years $\mathrm{BP}$ and widespread colonization by early horticultural villagers from 3,000 BP. Farming systems were based on starch root crops, mainly sweet and bitter manioc, sweet potatoes and, in water, rice. Between 1,600 and $500 \mathrm{BP}$, corn became a major food crop. According to Roosevelt (1992), pre-Columbian population density in Amazonia was much higher than it is today and was characterized by a high level of social organization. Chiefdoms on Marajó Island and near Santarém had thousands of inhabitants. There were, however, long periods in which settlements were abandoned (Meggers 1984, 1992a, b), 
perhaps due to the periodic overexploitation of resources or the outbreak of diseases or wars between tribes. Population density varied from 1.2 persons $\mathrm{km}^{-2}$ in the nutrient-poor uplands to two persons in the savannas and up to 28 persons (mean 14.6) in the nutrient-rich floodplains of the Amazon (Denevan 1976).

Elevated places for flood protection were constructed by these early inhabitants in the Pantanal, the Llanos de Moxos, and the Roraima and Orinoco savannas, the floodplains of Surinam, Ecuador, and Argentina, and the delta of the Magdalena River (Parsons and Bowen 1966; Denevan 1966, 1976; Roosevelt 1992). The swamps around Lake Titicaca were colonized by Uru Indians, who constructed houses on floating islands of totora reed.

Extended levees were built above the highest flood level to connect villages during high water, while complex channel systems allowed boat traffic inside the floodplains and between adjacent river systems, but also fish trapping as the water level decreased. Crop systems could be planted above the flood level by piling up the soil between parallel channels. Soils were fertilized by mulching with aquatic plants and enrichment using shells of bivalves and snails. In the soils of elevated places in the Pantanal (aterro de bugre), a new mineral, beidellite, was detected. Its high ion-exchange capacity increased soil fertility (Irion et al. 2010a, b). Prisoners may have been used to build earthworks and drain fields. Soon after the arrival of the Europeans, tribal organization was destroyed. Reduction of the native population by both slave raids and diseases introduced by the Europeans led to the abandonment of these labor-intensive management systems.

Today, population density in the floodplains reflects the nutrient status of these areas and access to them, as in preColumbian times, but also depends on access to markets and on infrastructure. The human population in Amazonian nutrient-rich whitewater river floodplains (várzeas) is much larger than that in nutrient-poor blackwater floodplains. The knowledge and customs of local traditional communities often derive from pre-Columbian times, as is the case for the caboclos of the Amazonian river floodplains and the pantaneiros of the Pantanal.

Many traditional management methods can be considered sustainable but the pressure to overexploit resources is increasing. Multiannual extreme hydrological events heavily affect the wetlands, with sometimes disastrous consequences for traditional communities, which have little economic resilience to overcome them. The highly wetlandadapted Uru Indians living in the totora swamps at the edges of Lake Titicaca suffered severely when, during an extreme multiannual dry period in the 1990s, the swamps dried out, causing the Indians to lose their source of livelihood.

Ongoing experiments are aimed at counteracting this pressure by implementing decentralized management forms, e.g., community-based fisheries management in the Brazilian Amazon (McGrath et al. 1999; Ruffino 1999). In the Sustainable Development Reserve of Mamirauá, near Tefé, in the Brazilian Amazon, a successful combination of wetland protection and sustainable management by the local population has been established, with the latter enabling fisheries, selective timber exploitation, and smallholder agriculture (Queiroz and Peralta 2010). In other wetlands, however, economic pressure threatens traditional environmentally-friendly management methods, e.g., those in the Pantanal, where efforts are required to improve the economic conditions of the traditional ranchers. These efforts could involve stimulating eco-tourism and developing markets for renewable wetland products such as honey or caiman eggs (for caiman farming), thus maintaining long-standing sustainable management (Junk et al. 2011b).

Ornamental fish trade is often criticized by environmentalists as detrimental to fish stocks because of high losses of specimens during capture, storage, and transport to the customer. However, this picture has been changed considerably by the introduction of quality standards. The middle Negro River is one of the centers in which ornamental fishes are collected. Soils and water in the area are extremely nutrient poor, and ornamental fish extraction is the major economic activity of the local population. The fishery methods employed are highly selective and do not damage the wetlands. Collapse of this activity would have dramatic consequences for the local population and the environment, since it would essentially force the local people into logging, palm heart extraction, and cattle ranching, all of which destroy the forest cover (Chao et al. 2001; Junk 2007).

\section{Role of wetlands in the landscape under global climate change}

\section{Reconstruction of the paleoclimate}

Studies of the paleoclimate in South America present a complex picture. Pollen records indicate a cold and wet climate during the late Pleistocene at the eastern slopes of the Andes (21,000-11,200 BP) and a lowering of the vegetation zones along the height gradient. Temperature and precipitation increased at the beginning of the Holocene and the vegetation belts moved slowly upwards, but there were some changes between dryer, wetter, cooler, and warmer periods. About 3,500 BP, today's climate and vegetation belts were established (Niemann and Behling 2008; Niemann et al. 2009).

Studies on the sediment characteristics at Lago Pollux, in Aisén Province in southern Chile, indicate glacier 
melting from 18,000 to 14,000 years BP in a dryer and warmer climate than before, and climate variability in the following 3,000 years. From 11,000 to 7,500 BP, a Nothofagus steppe-woodland developed that later became a closed Nothofagus forest, suggesting establishment of the present-day equitable precipitation regime (Markgraf et al. 2007).

Postglacial climate variability in central South America affected the regions in different ways, as shown by Behling and Safford (2009) for the Atlantic Forest near Rio de Janeiro. The Pantanal passed during the Holocene through different climatic episodes that are not yet fully understood (Assine and Soares 2004). The following climatic episodes can be distinguished: ?40,000-8,000 BP, cool and dry; 8,000-3,500 BP, warm and wet; 3,500-1,500 BP, warm and dry; and 1,500-present, warm and wet (Iriondo and Garcia 1993; Stevaux 2000).

According to the authors of the refuge theory (summarized by Haffer and Prance 2001), during glacial periods, the Amazonian climate was dryer and cooler, which led to fragmentation of the rainforest cover and the formation of forest refuges. Populations of forest species became isolated, passing through periods of speciation, whereas populations of savanna species were able to cross the Amazon basin along savanna corridors. During interglacial periods, the forest advanced into the savanna areas, allowing the spread of newly evolved forest species while isolating savanna populations. However, this hypothesis has been contested by other authors, who did not find evidence supporting a change in forest cover in the Amazonian lowlands (summarized in Colinvaux et al. 2001; Irion et al. 2010a, b; Hoorn et al. 2010). Between glacial and interglacial periods, changes in sea level of about $130 \mathrm{~m}$ led to considerable changes in the declivity of large South American rivers. Old river terraces can be found along the Amazon River up to 2,500 km inside the continent (Irion et al. 2010a, b).

The biome reconstructions of Latin America of Marchant et al. (2009) suggest a generally cool and dry climate at 18,000 $\pm 1,000$ year BP. Southernmost South America was dominated by cool grass/shrubland and a single site retains cool temperate rain forest, indicating that forest was present at some locations at the Last Glacial Maximum. In southeast Brazil, cool grass/shrubland was prevalent whereas Amazonian sites recorded tropical dry forest, warm temperate rain forest, and tropical seasonal forest. Differences between the modern climate and that of the $6,000 \pm 500$ year $\mathrm{BP}$ reconstruction are comparatively small and indicate biomes characteristic of drier climates in the north of the region with a slightly more mesic shift in the south. Cool temperate rain forest remains dominant in western South America. In northwestern South America, a number of sites evidence transitions from tropical seasonal forest to tropical dry forest and tropical rain forest to tropical seasonal forest.

Predictions of global climate change and the effect on wetlands

The Andes, as a geographic barrier, and the Amazon rain forest biome (Amazon River basin and adjacent forested river basins), which covers about 6.5 million $\mathrm{km}^{2}$, are unique geographic features that shape the climate of South America. The Amazon rain forest biome is of vital ecological importance but is also central to the global carbon cycle and as a driver of regional and global climate (Keller et al. 2009a, b). Heat and water vapor over the tropical belt rise to high altitudes and drive global atmospheric circulation (McClain et al. 2001; Nobre et al. 2009). About 50\% of the rain falling in the Amazon basin derives from evapotranspiration from the rain forest (Salati and Marques 1984), with a portion of the water vapor exported to southern savanna areas including the Pantanal. There is a raising concern about the impact of large scale deforestation of the Amazon rain forest on the regional water balance but also on global climate because of the liberation of large amounts of $\mathrm{CO}_{2}$ to the atmosphere (Marengo et al. 2009). Several large projects are ongoing about the contribution of the Amazon basin to the regional and global climate, such as the Large Scale Biosphere-Atmosphere Experiment in Amazônia (LBA), the Environmental Research Observatory (ORE) HYBAM (Geodynamical, Hydrological and Biogeochemical Control of Erosion/ Alteration and Material Transport in the Amazon Basin), and Amazonian Tall Tower Observatory (ATTO, under construction).

The predictions of the Intergovernmental Panel on Climate Change (IPCC 2007) regarding the consequences of global climate change in South America are still rather imprecise and somewhat contradictory. Scenarios of temperature increase for the year 2100 indicate values of $1.8-5.1^{\circ} \mathrm{C}$ (median $3.2^{\circ} \mathrm{C}$ ) and $1.7-3.9^{\circ} \mathrm{C}$ (median $2.5^{\circ} \mathrm{C}$ ) for northern and southern South America, respectively. Regional warming is expected to be greatest in the most continental regions, e.g., Central Amazonia.

Accelerated melting of snow and ice, including glaciers in Patagonia and the Andes, will reduce water storage and discharge-buffer capacity. IPCC predicts a sea-level rise of 20-60 cm until 2100, but new studies point to higher values between 0.75 and $1.9 \mathrm{~m}$ (Vermeer and Rahmstorf 2009; Overpeck and Weiss 2009). Precipitation may decrease slightly near the Caribbean coast as well as over large parts of Brazil, Chile, and Patagonia, but may increase in Colombia, Ecuador, and Peru, around the equator, and in southeastern South America. However, rainfall distribution during annual cycles may change, with 
precipitation increasing during the rainy season and decreasing during the dry season. Also, an increase of extreme multiannual and short-term climate events (El Niño and La Niña, heavy rains and droughts, heat waves) is predicted. This will lead in some areas to a reduction of groundwater-recharge rates, for instance, in northeastern Brazil. There is no doubt that the predicted changes in global climate will also heavily affect the wetlands.

The impact of the rise in temperature on the species composition of South American wetlands is difficult to predict, given the lack of ecophysiological data on wetland organisms. Wetland species of the Amazonian lowland rain forest, the Atlantic Coastal Forest, and the tropical and subtropical savannas have overcome considerable temperature changes over several glacial and interglacial periods. The anticipated raise in temperature will be faster than in previous periods, but most tropical and subtropical wetland species have a wide distribution range that points to a considerable ecophysiological elasticity. Accordingly, it can be expected that the anticipated rise in temperature will change the species composition of the respective communities but will not lead to mass extinction of wetland species.

On a continental scale, a shift of temperate and boreal species to higher latitudes and to higher altitudes in mountainous regions can be expected, along with an extension of mangroves further to the north and south, when adequate habitats are available. However, I oppose the prediction of Loarie et al. (2009), in which temperature driven highest ecosystem dislocation velocities are predicted for flooded grasslands, deserts, and mangroves. Occurrence of these ecosystems is certainly not correlated with temperature but with water availability. While the species composition may change with raising temperature, these and other tropical and subtropical ecosystems will be maintained at the same locality as long as hydrological conditions that reproduce them are suitable.

A major threat will be the increase of fires. In 2009, rainfall in the Pantanal reached about $1,400 \mathrm{~mm}$ and 2,488 wildfires were recorded. In 2010, rainfall was only about $800 \mathrm{~mm}$ and the number of wildfires rose to 5,341 (data on wildfires from Instituto Nacional de Pesquisas Espaciais (INPE), from satellite NOAA-15). Most of these fires were man-made. Ongoing studies by INAU indicate serious threats to forested habitats at periodically flooded savannas such as Pantanal and the Araguaia River floodplain because flood adapted tree species are sensitive to fire.

A climate model coupled with an Amazon vegetation model offered by the Hadley Center predicts the conversion of the Amazon rain forest to cerrado vegetation from 2050 to 2100 (Jenkins et al. 2005). In the Amazon rain forests and soils, about $75 \mathrm{Gt}$ of organic carbon are stored $\left(75 \times 10^{9} \mathrm{t}\right)$. Most of this carbon would be released to the atmosphere, reinforcing the greenhouse effect. Considering the large uncertainties in climate models and the lack of ecophysiological data for the highly diverse Amazonian rain forest, catastrophic scenarios such as this one are not helpful because they may counteract efforts to protect the rain forest. Why protect a forest that will collapse anyway in a few decades? Furthermore, the study's authors did not consider that about one-third of the Amazon rain forest area is periodically flooded or waterlogged and has to be considered wetland. This also has not been taken into account by any of the Amazonian climate and vegetation models. If the climate predictions of the IPCC turn out to be correct, the Amazon rain forest may to some extent change to a semideciduous forest (Malhi et al. 2009) with a dense network of evergreen riparian and floodplain forests. Nevertheless, strong protection efforts are required for forests and wetlands because human pressure to transform them into pasture and cropland is rising. This increases fire frequency in the man-made grasslands during dry periods, which destroys also connected forest patches and wetland vegetation.

Dramatic effects are to be expected for the wetlands in the coastal belts, but not because the coastal wetlands cannot cope with the predicted sea level rise. After the Last Glacial Maximum, the sea level rose over the next $\sim 10,000$ years at a mean of $1 \mathrm{~m}$ per century but coastal wetland species and communities managed to survive. From the last interglacial period, mean sea-level rises were even higher, about $1.6 \mathrm{~m}$ per century (Rohling et al. 2008). The problem will be the fact that the hinterland of coastal wetlands is increasingly occupied by humans, gradually squeezing coastal wetlands between the advancing sea and civil constructions, such as roads, industrial developments, and settlements. Long-term land-use planning is required in which the wetlands are allowed to slowly dislocate to higher areas whenever possible, as they will become, among other aspects, increasingly important for coastal zone protection in response to the increasing wind speeds and cyclones predicted also for South America (Marengo 2006; Greenpeace 2006). Sea lever rise will also affect the wetlands along the lower reaches of many large rivers extending the impact of the tide upriver and modifying flora and fauna accordingly.

Accelerated melting of snow and ice, including the glaciers in Patagonia and the Andes, will reduce water storage and the discharge-buffer capacity of rivers with catchments in the Andes. Together with the stronger periodicity in rainfall, indicated by the IPCC for large areas of South America, and stronger El Niño and La Niña events, accelerated snow melting in the Andes will increase the risk of high floods and severe low-water periods in all large rivers. Lower-order rivers will suffer heavy changes of discharge and flood pulses between dry and rainy seasons, 
and heavy oscillations in flood pulses during extreme rainfall events. In regions with longer dry seasons, lowerorder streams may shift from a permanent to an intermittent status, with dramatic effects for aquatic fauna and flora. Cox et al. (2008) examined the possible links of the heavy drought of Amazonia in 2005 to climate change. Their model suggests a probability of the 2005-like drought every second year by 2025 and a 9-in-10 years event in by 2060.

The increase in precipitation periodicity together with stronger El Niño and La Niña events will strongly impact rainwater-fed floodplains and swamps, which have a low hydrological buffer capacity. There will be an increased risk of wild fires, mostly in floodplains and swamps in tropical and subtropical regions, because of increased drought stress. This will lead to changes in the species compositions of plant and animal communities.

\section{Conclusions}

Wetlands cover a considerable portion of the South American subcontinent. While the total area is not known, it may be as high as $20 \%$ of the land's surface. The current state of knowledge about the occurrence, structures, and functions of the different wetland types varies considerably between regions, but is in many cases insufficient to contribute to the development of a modern policy for the sustainable use and protection of wetlands.

The rich water resources and relatively low human population of wetland regions provide the governments of South American countries, in many cases, with the opportunity to elaborate development schemes that reconcile wetland protection and economic development. However, in the existing legislation to protect and manage aquatic resources of most countries, wetlands do not play a role commensurate with either their size or their numerous benefits to humans and the landscape.

Costanza et al. (1997) provided an analysis of the average value of the "natural capital" of different ecosystems, including their goods, services, biodiversity, and cultural contributions. Wetlands and rivers were estimated

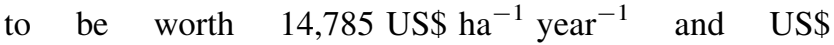
$8,498 \mathrm{ha}^{-1}$ year $^{-1}$ respectively, forests US\$ 969, and grasslands US\$232. This analysis certainly does not hold true for all South American wetlands. It shows, however, that the neglect of wetlands in national policies not only negatively impacts the ecology of these regions, but is also an enormous economic mistake. A comparison of intact mangroves in Thailand with converted mangroves for shrimp farming, and intact freshwater marshes in Canada with those converted to intensive farming showed considerable higher values of the intact wetlands (Balmford et al.
2002). Additional studies are required to determine and quantify the benefits of wetlands and to calculate their economic value to the societies in which they are located. This will facilitate discussions with politicians and stakeholders about wetland-friendly management methods and wetland protection.

Discussions about sustainable wetland management and protection in light of global climate change scenarios must differentiate between: (1) current direct human impacts on wetlands at the local and regional scale, and (2) effects of global climate change, which in most areas of South America are still to come.

Wetland deterioration is accelerating. The negative human impacts acting today on most ecosystems, including wetlands, are a result of human activities and policies. They affect the sub-continent at regional and national levels, forcing governments to react to them independently of predicted global climate changes (Vörösmarty et al. 2000). For instance, the periodic drying out and flashflooding of lower-order streams in agricultural areas is not the consequence of global climate change but of the largescale modification of catchment vegetation, including riparian vegetation and headwater wetlands. Measures to stop and reverse these developments have to be implemented now in order to avoid further deterioration because wetland maintenance is always cheaper than wetland restoration. Neither the heavy floods nor the droughts that affected the Amazon River floodplain during the last years can be attributed to global climate change, because similar floods and droughts happened already earlier. However, the effects on human populations living along the floodplain are extremely negative, forcing governments to react to them now. The development of an efficient water-level forecast system is a first step in that direction (Schöngart and Junk 2007). When discussing the protection of national resources, there is no argument that supports waiting for international agreements.

Predictions of the IPCC point to a rise in sea level and considerable changes in the total amounts and/or distribution patterns of rainfall, snowfall, and glacier melting, all of which will affect, to different degrees, South American ecoregions, including wetlands. In the future, intact wetlands will play an important role in buffering the expected changes in the hydrological cycle and in diminishing its negative social, economic, and ecological impacts.

Actions to reduce the extent of global climate change require international agreements. These must take into account the ability of wetlands to act as carbon sinks, for instance, when negotiating carbon equivalents. But these activities will show effects only over the long-term as will the impacts of global climate change in most parts of South America. I predict that by the year 2040 and probably much later, impending changes in human population and 
economic development will affect most South American ecosystems in general, and the wetlands in particular, to a much larger degree than will changes in global climate. However, we have to bear in mind that in a few decades, climate changes will underlie a dramatic deterioration in the status of wetlands and their functions, testifying to the negatively effects of our current short-term development actions.

\section{References}

Abe DS, Tundisi JG, Vannucci D and Sidagis-Galli C 2006 Avaliação da capacidade de remoção de nitrogênio em uma várzea da cabeceira do reservatório de Guarapiranga, região metropolitana de São Paulo. In: Tundisi JG, Matsumura-Tundisi T, SidagisGalli C (eds) Eutrofisação na América do Sul: Causas, consequiências e tecnologias de gerenciamento e controle. Instituto Internacional de Ecologia, São Carlos-SP, Brazil, pp 241-253

Agostinho AA, Pelicice FM, Petry AC, Gomes LC, Júlio HF Jr (2007) Fish diversity in the upper Paraná River basin: habitats, fisheries, management and conservation. Aquat Ecosyst Health Manage 10(2):174-186

Assine ML, Soares PC (2004) Quaternary of the Pantanal, westcentral Brazil. Quatern Int 114:23-34

Baigún CRM, Puig A, Mintoti PG, Kandus P, Quintana R, Vicari R, Bo R, Oldani NO and Nestler JA (2008) Resource use in the Paraná River Delta (Argentina): moving away from an ecohydrological approach? Ecohydrol Hydrobiol 8(2-4):245-262

Balmford A, Bruner A, Cooper P, Costanza R, Farber S, Green RE, Jenkins M, Jefferiss P, Jessamy V, Madden J, Munro K, Myers N, Naeem S, Paavola J, Rayment M, Rosendo S, Roughgarden J, Trumper K and Turner RK (2002) Economic reasons for conserving wild nature. Science 297:950-953

Bayley PB and Petrere M Jr (1989) Amazon fisheries: Assessment methods, current status, and management options. Canadian Special Publication of Fisheries and Aquatic Sciences 106:385-398

Behling H, Safford HD (2009) Late-glacial and Holocene vegetation, climate and fire dynamics in the Serra dos Orgâos Mountains of Rio de Janeiro State, southeastern Brazil. Glob Change Biol 16(6):1661-1671

Blanco DE, Balze de la VM (eds) (2004) Los turbales de la Patagonia: Bases para su inventário y la conservación de su biodiversidad. Wetlands International-America del Sur No 19, Buenos Aires, Argentina

Bozelli RL, Esteves F de A, Roland F (eds) (2000) Lago Batata: impacto e recuperação de um ecossistema Amazônico. UFRJ/ SBL, Brazil

Brinson MM, Malvárez AI (2002) Temperate freshwater wetlands: types, status, and threats. Environ Conserv 29(2):115-133

Canevari P, Blanco DE, Bucher EH, Castro G, Davidson I (1999) Humedales de la Argentina: clasificación, situación actual, conservación y legislación. Wetlands International 46, 208 pp

Chao NL, Petry P, Prang G, Sonneschien L, Tlusty M (eds) (2001) Conservation and management of ornamental fish resources of the Rio Negro Basin, Amazonia, Brazil—Project Piaba. Editora da Universidade do Amazonas, Manaus

Colinvaux PA, Irion G, Räsänen ME, Bush MB, Nunes de Mello JAS (2001) A paradigm to be discarded: geological and paleoecological data falsify the Haffer and Prance refuge hypothesis of Amazonian speciation. Amazoniana 16:609-646
Collantes M and Faggi AM (1999) Los humedales del sur de Sudamérica. In: Malvárez AI (ed) Tópicos sobre humedales subtropicales y templados de Sudamérica. UNESCO, Montevideo, pp 15-25

Costanza R, d'Arge R, de Groot R, Farber S, Grasso M, Hannon B, Limburg K, Naeem S, O’Neill RV, Paruel J, Raskin RG, Sutton $P$ and Van den Belt M (1997) The value of the world's ecosystem services and natural capital. Nature 387:253-260

Cox P, Harris P, Huntingford C, Betts R, Collins M, Jones C, Jupp T, Marengo J, Nobre C (2008) Increase risk of Amazonian drought do to decreasing aerosol pollution. Nature 453:212-216

Deil U (2005) A review of habitats, plant traits and vegetation of ephemeral wetlands-a global perspective. Phytocoenologia 35(2-3):533-705

Denevan WM (1966) The aboriginal cultural geography of the Llanos de Moxos of Bolivia. Ibero-Americana 48, University of California Press, Berkeley

Denevan WM (1976) The aboriginal population of Amazonia. In: Denevan WM (ed) The native population of the Americas. University of Wisconsin Press, Madison, pp 205-234

Drago EC, Wantzen KM, Paira AR (2008) The Lower Paraguay riverfloodplain habitats in the context of the Fluvial Hydrosystem Approach. Ecohydrol Hydrobiol 8(1):49-66

Eva HD, Belward AS, Miranda EE de, Bella CM di, Gond V, Huber O, Jones S, Sgrenzaroli M and Fritz S (2004) A land cover map of South America. Global Change Biol 10:731-744

Fearnside PM (1989) Brazil's Balbina Dam: environment versus the legacy of the pharaohs in Amazônia. Environ Manage 13(4):401-423

Fearnside PM (1995) Hydroelectric dams in the Brazilian Amazon as sources of "greenhouse gases". Environ Conserv 22:7-19

Galdino S, Vieira LM and Pellegrin LA (2006) Impactos ambientais e socioeconômicos na bacia do Rio Taquari-Pantanal. Embrapa Pantanal, Corumbá, MS

Galvis G, Mojica JI (2007) The Magdalena River fresh water fishes and fisheries. Aquat Ecosyst Health Manage 10(2):127-139

Gopal B, Junk WJ, and Davis JA (2000, 2001) Biodiversity in wetlands: assessment, function and conservation. Part 1 and 2. Backhuys Publishers, Leiden

Gopal B, Junk WJ, Finlayson CM and Breen CM (2008) Present state and future of tropical wetlands. In: Polunin N (ed) Aquatic Ecosystems. Cambridge University Press, Cambridge, UK for Foundation for Environmental Conservation, pp 142-154

Goulding M (1980) The fishes and the forest: explorations in Amazonia natural history. California University Press, Berkeley

Goulding M, Carvalho ML and Ferreira EG (1988) Rio Negro: rich life in poor water. SPB Academic Publishing bv, The Netherlands

Goulding M, Smith NJH and Mahar DJ (1996) Floods of fortune: ecology and economy along the Amazon. Columbia University Press, New York

Greenpeace (2006) Mudanças climáticas, mudanças de vida: como o aquecimento global já afeta o Brazil. Greenpeace-Brazil, São Paulo, http://www.greenpeace.org.br

Haffer J, Prance GT (2001) Climatic forcing of evolution in Amazonia during the Cenozoic: on the refuge theory of biotic differentiation. Amazoniana 16:579-607

Hamilton SK, Sippel SJ, Melack JM (1996) Inundation patterns in the Pantanal wetland of South America determined from passive microwave remote sensing. Archiv für Hydrobiologie 137:1-23

Hamilton SK, Sippel SJ, Melack JM (2004) Seasonal inundation patterns in two large savanna floodplains of South América: the Llanos de Moxos (Bolivia) and the Llanos del Orinoco (Venezuela and Colombia). Hydrol Process 18:2103-2116

Heckman CW (1998) The Pantanal of Poconé. Kluwer, Den Haag

Hoorn C, Wesselingh FP, ter Steege H, Bermudez MA, Mora A, Sevink J, Sanmartín I, Sanchez-Mesenguer A, Anderson CL, 
Figueiredo JP, Jaramillo C, Riff D, Negri FR, Hooghiemstra H, Lundberg J, Stadler T, Särkinen T, Antonelli A (2010) Amazônia through time: andean uplift, climate change, landscape evolution and biodiversity. Science 330:927-931

Huszar P, Petermann P, Leite A, Resende E, Schnack E, Schneider E, Francesco F, Rast G, Schnack J, Wasson J, Garcia Lozano L, Dantas M, Obrdlik P and Pedroni R (1999) Fact or fiction: a review of the Hydrovia Paraguay-Paraná official studies. Full report and executive summary, Toronto, Canada, WWF

IPCC (2007) Climate Change 2007: synthesis report: Contribution of Working Groups I, II and III to the fourth assessment report of the Intergovernmental Panel on Climate Change. IPCC, Geneva, Switzerland, $104 \mathrm{pp}$

Irion G, Buchas H, Junk WJ, Nunes da Cunha C, Morais JO de, and Kasbohm J (2010) Aspects of geological and sedimentological evolution of the Pantanal plain. In: Junk WJ, da Silva CJ, Nunes da Cunha C and Wantzen KM (eds) The Pantanal: ecology, biodiversity and sustainable management of a large neotropical seasonal wetland. Pensoft, Sofia-Moscow 47-70

Irion G, Mello JASN de, Morais J, Piedade MTF, Junk WJ and Garming L (2010) Development of the Amazon valley during the Middle to Late Quaternary: sedimentological and climatological observations. In: Junk WJ, Piedade MTF, Wittmann F, Schöngart J, Parolin P (eds) Central Amazonian floodplain forests: ecophysiology, biodiversity and sustainable management. Springer, Berlin/Heidelberg/New York 27-42

Iriondo MH, Garcia NO (1993) Climatic variations in the Argentine plains during the last 18,000 years. Palaeogeogr Palaeoclimatol Palaeoecol 101:209-220

Iriondo MH, Paggi JC and Parma MJ (2007) The Middle Paraná River: limnology of a subtropical wetland. Springer, Berlin/Heidelberg

Jenkins G, Betts R, Collins M, Griggs D, Lowe J, Wood R (2005) Stabilizing climate to avoid dangerous climate change-a summary of relevant research at the Hadley Centre. Department for Environment Food and Rural Affairs, Met Office Hadley Centre, Exeter, UK

Junk WJ (1993) Wetlands of tropical South América. In: Whigham D, Hejny S, Dykyjova D (eds) Wetlands of the world I. Kluwer Academic Publishers, Dordrecht, pp 679-739

Junk WJ (ed) (1997a) The Central Amazon floodplains: ecology of a pulsing system. Ecological Studies, vol 126, Springer, Berlin/ Heidelberg/New York

Junk WJ (1997b) Structure and function of the large central Amazonian river floodplains: synthesis and discussion. In: Junk WJ (ed) The Central Amazon floodplains: ecology of a pulsing system. Ecological Studies, vol 126, Springer, Berlin/Heidelberg/New York, pp 455-472

Junk WJ (2005) Flood pulsing and the linkages between terrestrial, aquatic, and wetland systems.-. Proc Int Assoc Theor Appl Limnol 29(1):11-38

Junk WJ (2007) Freshwater fishes of South America: their biodiversity, fisheries, and habitats-a synthesis. Aquat Ecosyst Health Manage 10(2):228-242

Junk WJ, Piedade MTF (1993) Herbaceous plants in the floodplain near Manaus: species diversity and adaptations to the flood pulse. Amazoniana 12:467-484

Junk WJ and Wantzen KM (2004) The Flood Pulse Concept: new aspects, approaches, and applications-an update. In: Welcomme RL and Petr T (eds) Proceedings of the Second International Symposium on the Management of Large Rivers for Fisheries, vol 2. Food and Agriculture Organization \& Mekong River Commission. RAP Publication 2004/16. FAO Regional Office for Asia and the Pacific, Bangkok, pp 117-149

Junk WJ, Bayley PB, Sparks RE (1989) The Flood Pulse Concept in River-Floodplain Systems. Special Publication of the Can J Fish Aquat Sci 106:110-127
Junk WJ, Ohly JJ, Piedade MTF and Soares MGM (eds) (2000) The central Amazon floodplain: actual use and options for a sustainable management. Backhuys Publishers, Leiden

Junk WJ, Nunes da Cunha C, Wantzen KM, Petermann P, Strüssmann C, Marques MI and Adis J (2006) Biodiversity and its conservation in the Pantanal of Mato Grosso, Brazil. Aquat Sci 68(3):278-309

Junk WJ, Nunes de Mello JAS (1987) Impactos ecológicos das represas hidrelétricas na bacia amazônica brasileira. Tübinger Georg. Studien 95:367-385

Junk WJ, Soares MGM, Bayley PB (2007) Freshwater fishes of the Amazon River basin: their biodiversity, fisheries and habitats. Aquat Ecosyst Health Manage 10(2):153-173

Junk WJ, Piedade MTF, Wittmann F, Schöngart J and Parolin P (eds) (2010) Amazon floodplain forests: ecophysiology, biodiversity and sustainable management. Ecological Studies, vol 210, Springer, Berlin/Heidelberg/New York

Junk WJ, da Silva CJ, Nunes da Cunha C and Wantzen KM (eds) (2011a) The Pantanal of Mato Grosso: ecology, biodiversity and sustainable management of a large neotropical seasonal wetland. Pensoft, Sofia-Moscow

Junk WJ, Piedade MTF, Schöngart J, Cohn-Haft M, Adeney JM, Wittmann F (2011b) A classification of major naturally-occurring Amazonian lowland wetlands. Wetlands 31:623-640

Junk WJ, Wantzen KM, Nunes da Cunha C and da Silva CJ (2011b) Ecology, biodiversity and sustainable management of the Pantanal: a synthesis. In: Junk WJ, da Silva CJ, Nunes da Cunha C, Wantzen KM (eds) The Pantanal of Mato Grosso: ecology, biodiversity and sustainable management of a large neotropical seasonal wetland. Pensoft, Sofia-Moscow, pp 835-857

Kalliola R, Puhakka M, Danjoy W (1993) Amazônia peruana: vegetación húmeda tropical em el Llano subandino. Projecto Amazonia Universidad de Turku e Oficina Nacional de Evaluación de Recursos Naturales, Lima, p 265

Kandus P, Minotti P, Malvárez AI (2008) Distribution of wetlands in Argentina estimated from soil charts. Acta Sci Biol Sci 30(4):403-409

Keller M, Bustamante M, Gash J and Dias PS (2009) Amazonia and global change. Geophys Monogr 186, American Geophysical Union, Washington, DC 565 pp

Keller M, Bustamante M, Gash J and Dias PS (eds) (2009) Amazonia and global change. Geophys Monogr 186, American Geophysical Union, Washington, DC

Kemenes A, Forsberg BR and Melack JM (2007) Methane release below a hydroelectric dam. Geophys Res Lett 34:L12809. doi: 10.1029/2007GL029479

King JM, Tharme RE, Brown CA (1999) Definition and implementation of instream flows. Thematic Report for the World commission on Dams. Southern Waters Ecological Research and Consulting, Cape Town, p 87

Lacerda LD (2001) Mangrove ecosystems: functions and management. Springer, Berlin/Heidelberg/New York

Lewis WM Jr, Weibezahn FH, Saunders JF III, Hamilton SK (1990) The Orinoco River as an ecological system. Interciencia 15:346-357

Lewis WM Jr., Hamilton SK, Lasi MA, Rodriguez M, Saunders III JF (2000) Ecological determinism on the Orinoco floodplain. Bioscience 50:681-692

Loarie SR, Duffy PB, Hamilton H, Asner GP, Field CB, Ackerly DD (2009) The velocity of climate change. Nature 462:1052-1055

Machado RB, Harris MB, Silva SM and Ramos Neto MB (2011) Human impacts and environmental problems in the Brazilian Pantanal. In: Junk WJ, da Silva CJ, Nunes da Cunha C and Wantzen KM (eds) The Pantanal of Mato Grosso: ecology, biodiversity and sustainable management of a large neotropical seasonal wetland. Pensoft, Sofia-Moscow, pp 719-739 
Malhi Y, Aragão LEOC, Galbraight D, Huntingford C, Fisher R, Zelazowski P, Sitch S, McSweeney C and Meir P (2009) PNAS 106(49):20610-20615

Malvárez AI, Bó RF (2004) Documentos del Curso-Taller "Bases ecológicas para la classificación e inventario de humedales en Argentina. Secretaria de Ambiente e Desarollo Sustentable, Ministério de Salud de la Nación, Buenos Aires

Marchant R, Cleef A Harrison SP, Hooghiemstra H, Markgraf V, vanBoxel J, Ager T, Almeida L, Anderson R, Baied C, Behling $\mathrm{H}$, Berrio JC, Burbridge R, Björck S, Byrne R, Bush M, Duivenvoorden J, Flenley J, De Oliveira P, van Geel B, Graf K, Gosling WD, Harbele S, van der Hammen T, Hansen B, Horn S, Kuhry P,Ledru M-P, Mayle F, Leyden B, Lozano-García S, Melief AM, Moreno P, Moar NT, Prieto A, van Reenen G, SalgadoLabouriau M, Schäbitz F, Schreve-Brinkman EJ, Wille M (2009) Pollen-based biome reconstructions for Latin America at 0, 6000 and 18000 radiocarbon years ago. Climate Past 5:725-767

Marengo JA (2006) Mudanças climáticas globais e seus efeitos sobre a biodiversidade: Caracterização do clima atual e definição das alterações climáticas para o território Brasileiro ao longo do Século XXI. Biodiversidade 26, Ministério do Meio Ambiente, Secretaria de Biodiversidade e Florestas, Brasília

Marengo JA and Nobre CA (2001) General characteristics and variability of climate in the Amazon basin and its links to the global climate system. In: McClain ME, Victoria RL and Richey JE (eds) The biogeochemistry of the Amazon basin and its role in a changing world. Oxford University Press, Oxford, pp 17-41

Marengo JA, Nobre CA, Betts RA, Cox PM, Sampaio G and Salazar L (2009) Global warming and climate change in Amazônia: climate-vegetation feedback and impacts on water ressources. In: Keller M, Bustamante M, Gash J and Dias PS (eds) Amazonia and global change. Geophysical Monograph, vol 186, American Geophysical Union, Washington, DC, pp 273-292

Markgraf V, Whitlock C, Haberle S (2007) Vegetation and fire history during the last 18,000 cal yr B.P. in Southern Patagonia: Mallín Pollux, Coyhaique, Province Aisén $\left(45^{\circ} 41^{\prime} 30^{\prime \prime} \mathrm{W}, 640 \mathrm{~m}\right.$ elevation). Palaeogeogr Palaeoclimatol Palaeoecol 254:492-507

McClain ME, Victoria RL and Richey JE (2001) The biogeochemistry of the Amazon basin and its role in a changing world. Oxford University Press, New York

McGrath D, Castro F de, Câmara E, Futemma C (1999) Community management of floodplain lakes and sustainable development of Amazonian fisheries. In: Padoch C, Ayres JM, Pinedo-Vasquez M, Henderson A (eds) Várzea: diversity, development and conservation of Amazonia's whitewater floodplains. Advances in Economic Botany, vol 13. The New York Botanical Garden Press, Bronx, New York, pp 59-82

Meade RH (1996) River-sediment inputs to major deltas. In: Milliman JD, Haq BU (eds) Sea-level rise and coastal subsidence: causes, consequences, and strategies. Kluwer Academic Publishers, Dordrecht, The Netherlands, pp 63-85

Meggers BJ (1984) The indigenous peoples of Amazonia, their cultures, land use patterns and effect on the landscape and biota. In: Sioli $\mathrm{H}$ (ed) The Amazon-Limnology and landscape ecology of a mighty tropical river and its basin. Monographiae Biologicae. Junk, Dordrecht, pp 627-648

Meggers BJ (1987) The early history of man in Amazonia. In: Whitmore TC and Prance GT (eds) Biogeography and quaternary history in tropical America. Clarendon Press, Oxford, pp 151-174

Meggers BJ (1992a) Prehistoric population density in the Amazon basin. In: Verano JW and Ubelaker DH (eds) Disease and demography in the Americas. Smithsonian Institution Press, Washington/London, pp 197-205

Meggers BJ (1992b) Review of "Mound builders of the Amazon: geophysical archaeology on Marajó Island, Brazil" by Roosevelt, A.C. J Field Archaeol 19:399-404
Melack JM (2004) Tropical freshwater wetlands. In: Ustin S (ed) Manual of remote sensing, vol 4. Remote sensing for natural resources management and environmental monitoring. Wiley, New York, pp 319-343

Melack JM and Forsberg BR (2001) Biogeochemistry of Amazonian floodplain lakes and associated wetlands. In: McClain ME, Victoria RL and Richey JE (eds) The biogeochemistry of the Amazon basin and its role in a changing world. Oxford University Press, Oxford, pp 235-274

Melack JM, Hess LL (2010) Remote sensing of the distribution and extent of wetlands in the Amazon basin. In Junk WJ, Piedade MTF, Wittmann F, Schöngart J and Parolin P (eds) Amazon floodplain forests: ecophysiology, biodiversity and sustainable management. Ecological Studies, vol 210, Springer, Berlin/ Heidelberg/New York, pp 43-59

Melack JM, Novo EMLM, Forsberg BR, Piedade MTF and Maurice L (2009) Floodplain ecosystem processes. In: Keller M, Bustamante M, Gash J and Dias PS (eds) Amazonia and global change. Geophysical Monograph, vol 186, American Geophysical Union, Washington, DC, pp 525-541

Milliman JD, Meade RH (1983) Worldwide delivery of river sediment to the oceans. J Geol 91:1-21

Ministerio del Medio Ambiente (2002) Política nacional para humedales interiores de Colombia: Estrategias para su conservación y uso racional. Republica de Colombia, Ministerio del Medio Ambiente, Consejo Nacional Ambiental, Bogotá

Mitsch WJ, Gosselink JG (2007) Wetlands. John Wiley \& Sons Inc., Hoboken

Navarro G, Maldonado M (2002) Geografía ecológica de Bolivia: Vegetación y Ambientes Acuáticos. Centro de Ecología Simón I. Patino, Departamento de Difusión. Cotchabamba, Bolivia

Neiff JJ (2001) Humedales de la Argentina: sinopsis, problemas y perspectivas futuras. In: Cirelli $\mathrm{AF}$ (ed) El agua en Iberoamérica. Funciones de los humedales, calidad de vida y agua segura. Publ CYTED, pp 83-112

Niemann H, Behling H (2008) Late Quaternary vegetation, climate and fire dynamics inferred from the El Tiro record in the southeastern Ecuadorian Andes. J Quat Sci 23(3):203-212

Niemann H, Haberzettl T, Behling H (2009) Holocene climate variability and vegetation dynamics inferred from the (11,700 cal yr BP) Laguna Rabadilla de Vaca sediment record in the southeastern Ecuadorian Andes. The Holocene 19(2):307-316

Nobre CA, Obregón GO, Marengo JA, Fu R and Povera G (2009) Characteristics of Amazonian climate: main features. In: Keller M, Bustamante M, Gash J and Dias PS (eds) Amazonia and global change. Geophysical Monographm, vol 186. American Geophysical Union, Washington, DC, pp 149-162

Nogueira F and Junk WJ (2000) Mercury from goldmining in Amazon wetlands: contamination sites, intoxication levels and dispersion pathways. In: Junk WJ, Ohly JJ, Piedade MTF and Soares MGM (eds) The Central Amazon Floodplain: actual use and options for a sustainable management. Backhuys Publishers b.v., Leiden, pp 477-503

Nunes da Cunha C and Junk WJ (2011) A preliminary classification of habitats of the Pantanal of Mato Grosso and Mato Grosso do Sul, and its relation to national and international classification systems. In: Junk WJ, da Silva CJ, Nunes da Cunha C and Wantzen KM (eds) The Pantanal: ecology, biodiversity and sustainable management of a large neotropical seasonal wetland. Pensoft, Sofia-Moscow 127-142

Overpeck JT, Weiss JL (2009) Projections of future sea level becoming more dire. PNAS 106(51):21461-21462

Padoch C, Ayres JM, Pinedo-Vasquez M, Henderson A (1999) Várzea: diversity, development, and conservation of Amazonia's whitewater floodplains. The New York Botanical Garden Press, New York, p 407 
Paoli C and Schreider M (2000) El Rio Paraná en su tramo médio: Contribuición al conocimiento y prácticas ingenieriles em um gran rio de llanura. Centro de Publicaciones Universidad Nacional Del Litoral, Santa Fé, Argentina

Parsons JJ, Bowen WA (1966) Ancient ridged fields of San Jorge River floodplain, Colombia. Geogr Rev 56(3):317-343

Pascual MA, Cussac V, Dyer B, Soto D, Vigliano P, Ortubay S, Macchi C (2007) Freshwater fishes of Patagonia in the 21st Century after a hundred years of human settlement, species introductions, and environmental change. Aquat Ecosyst Health Manage 10(2):212-227

Pott VJ and Pott A (2000) Plantas Aquáticas do Pantanal. EMBRAPA, Brasília

Pouilly M, Beck SG, Moraes RM, Ibenes C (2004) Diversidad biológica en la Llanura de inundación del Rio Mamoré. Importância ecológica de la dinámica fluvial. Centro de Ecología Simón I. Patino, Santa Cruz, Bolívia

Queiroz HL and Peralta N (2010) Protected areas in the Amazonian várzea and their role in its conservation: the case of Mamirauá Sustainable Development Reserve (MSDR). In: Junk WJ, Piedade MTF, Wittmann F, Schöngart J and Parolin P (eds) Amazon floodplain forests: Ecophysiology, biodiversity and sustainable management. Ecological studies, vol 210, Springer, Berlin/Heidelberg/New York, pp 465-483

Quirós R, Bechara JA, de Resende EK (2007) Fish diversity and ecology, habitats and fisheries for the un-dammed riverine axis Paraguay-Paraná-Rio de la Plata (Souther South America). Aquat Ecosyst Health Manage 10(2):187-200

Rasera MF, Ballester MVR, Krusche AV, Salimon C, Montebelo LA, Alin SR, Victoria RL, Richey JE (2008) Estimating the surface area of small rivers in the southwestern Amazon and their role in $\mathrm{CO}_{2}$ outgassing. Earth Interact 12(6):1-16

Rodríguez MA, Winemiller KO, Lewis WM Jr, Baechle DCT (2007) The freshwater habitats, fishes, and fisheries of the Orinoco River basin. Aquat Ecosyst Health Manage 10(2):140-152

Rohling EJ, Grant K, Hemleben Ch, Diddall M, Hoogakker BAA, Bolshaw M, Kucera M (2008) High rates of sea-level rise during the last interglacial period. Nat Geosci 1:38-42

Roosevelt AC (1992) Mound builders of the Amazon: geophysical archaeology on Marajó Island, Brazil. J Amazon Geophys Archaeol Marajo Island 19:399-404

Roosevelt AC (1999) Twelve thousand years of human-environment interaction in the Amazon Floodplain. In: Padoch C, Ayres JM, Pinedo-Vasquez M, Henderson A (eds) Várzea: diversity, development, and conservation of Amazonia's whitewater floodplains. The New York Botanical Garden Press, New York, pp 371-392

Ruffino ML (1999) Fisheries development in the lower Amazon River. In: Padoch C, Ayres JM, Pinedo-Vasquez M and Henderson A (eds) Várzea: diversity, development and conservation of Amazonia's whitewater floodplains. Advances in Economic Botany, vol 13. The New York Botanical Garden Press, Bronx, pp 101-111

Salati E, Marques J (1984) Climatology of the Amazon region. In: Sioli H (ed) The Amazon-limnology and landscape ecology of a mighty tropical river and its basin. Monographiae Biologicae. Dr. W. Junk Publishers, Dordrecht, pp 85-126

Salo J, Kalliola R, Häkkinen I, Mäkinen Y, Niemelä P, Puhakka M, Coley PD (1986) River dynamics and the diversity of Amazon lowland forest. Nature 322:254-258

Sato Y, Godinho HP (2004) Migratory fishes of the São Francisco River. In: Carolsfiled J, Harvey B, Ross C and Baer A (eds) Migratory fishes of South America. World Fisheries Trust, IDRC, World Bank, New York, USA, pp 199-232

Schöngart J and Queiroz HL de (2010) Traditional timber harvesting in the central Amazonian floodplain forests. In: Junk WJ,
Piedade MTF, Wittmann F, Schöngart J and Parolin P (eds) Amazon floodplain forests: ecophysiology, biodiversity and sustainable management. Ecological Studies, vol 210. Springer, Berlin/Heidelberg/New York, pp 419-436

Schöngart J, Junk WJ (2007) Forecasting the flood-pulse in Central Amazonia by ENSO-indices. J Hydrol 335:124-132

SIDRA-Sistema IBGE de Recuperação Automática (2011) Censo Demográfico e da Contagem da População. http://www.sidra. ibge.gov.br/bda/popul/default.asp. Accessed 18 June 2011

Sioli H (ed) (1984) The Amazon—limnology and landscape ecology of a mighty tropical river and its basin. Monographiae Biologicae. Dr. W. Junk Publishers, Dordrecht

Sippel SJ, Hamilton SK, Melack JM, Novo EMM (1998) Passive microwave observations of inundation area and the area/stage relation in the Amazon River floodplain. Int J Remot Sens 19:3055-3074

Smith NJH (1999) The Amazon River Forest: a natural history of plants, animals, and people. Oxford University Press, New York

Sousa Jr PT, Piedade MTF, Candotti E (2011) Letter to Nature. Nature 478:458

Stevaux JC (2000) Climatic events during the late Pleistocene and Holocene in the upper Parana River: correlation with NE Argentina and South-Central Brazil. Quatern Int 72:73-85

Tharme RE (2003) A global perspective on environmental flow assessment: emerging trends in the development and application of environmental flow methodologies for rivers. River Res Appl 19:397-441

Thomaz SM, Agostinho AA and Hahn NS (2004) The Upper Paraná River and its floodplain: physical aspects, ecology and conservation. Backhuys Publishers, Leiden

Tollefson J (2011) Brazil revisits forest code. Nature 476:259-260

Vásquez E (1989) The Orinoco River: a review of hydrobiological research. Regul Rivers Res Manag 3:381-392

Vermeer M, Rahmstorf S (2009) Global sea level linked to global temperature. PNAS 106(51):21527-21532

Vieira Rd S (2000) Legislation and the use of Amazonian floodplains. In: Junk WJ, Ohly JJ, Piedade MTF and Soares MGM (eds) The central Amazon floodplain: actual use and options for a sustainable management. Backhuys Publishers, Leiden, pp 505-533

Vila I, Pardo R, Scott S (2007) Freshwater fishes of the Altiplano. Aquat Ecosyst Health Manage 10(2):201-211

Vörösmarty CJ, Green P, Salisbury J and Lammers RB (2000) Global water resources: vulnerability from climate change and population growth. Science 289:284-288

Wantzen KM, Drago E, Da Silva CJ (2005) Aquatic habitats of the Upper Paraguay River-Floodplain-System and parts of the Pantanal. Ecohydrol Hydrobiol 5(2):107-126

Weibezahn FH, Alvarez H and Lewis Jr WM (1990) The Orinoco River as an ecosystem. Impresos Rubel CA, Caracas

Wittmann F, Schöngart J, Montero JC, Motzer T, Junk WJ, Piedade MTF, Queiroz HL,Worbes M (2006) Tree species composition and diversity gradients in white-water forests across the Amazon basin. J Biogeogr 33:1334-1347

Wittmann F, Schöngart J and Junk WJ (2010) Phytogeography, species diversity, community structure and dynamics of central Amazonian floodplain forests. In: Junk WJ, Piedade MTF, Wittmann F, Schöngart J and Parolin P (eds) Amazon floodplain forests: ecophysiology, biodiversity and sustainable management. Ecological studies, vol 210. Springer, Berlin/Heidelberg/ New York, pp 61-102

World Commission of Dams (ed) (2000) Dams and Development. Earthscan Publications Ltd, London

Wurtsbaugh WA, Tapia RA (1988) Mass mortality of fishes in Lake Titicaca (Peru-Bolivia) associated with the protozoan parasite Ichthyophthirius multifiliis. Trans Am Fish Soc 117:213-217 